\title{
Stakeholder Participation in Planning of the Protected Natural Areas: Slovenia
}

\author{
Mojca Nastran \\ Biotechnical Faculty, University of Ljubljana, Slovenia \\ e-mail: nastran.mojca@gmail.com
}

Janez Pirnat

Biotechnical Faculty, University of Ljubljana, Slovenia

e-mail: janez.pirnat@bf.uni-lj.si

\begin{abstract}
The participation of stakeholders in the planning of protected natural areas is growing significantly. It enhances their trust in protection aims and management measures. Limited time and finances, however, often reduce the impact of stakeholder participation on the level of information and education, thus usually resulting in insufficient implementation of choices regarding nature conservation.

The article describes the main stages of stakeholder participation planning, thus enabling us to determine the identity of key stakeholders, the planned participation level and the methods used to achieve it. Furthermore, a detailed analysis of the participation of stakeholders and the public in the planning of protected areas in Slovenia is carried out using two examples: the founding of the Regional Park Snežnik and the shaping of the Natura 2000 areas. Stakeholder participation and communication while founding the Regional Park Snežnik was a planned one. However, the foundation was terminated before it was accomplished and one of the reasons was a decreasing public support of the park. The shaping of the Natura 2000 network was accompanied by a vast communicative project dealing with the problem of how to approach numerous stakeholders in a short period of time given. The article presents the reasons why the implementation of Natura 2000 in Slovenia progresses slowly and the guidelines for its improvement.
\end{abstract}

Key words: the Aarhus convention, Forest service, Matra, Natura 2000, participation methodology, regional park Snežnik-Slovenia, stakeholder analysis, stakeholder involvement.

\section{Introduction}

It is impossible for any governmental or non-governmental organization to permanently and successfully protect the naturally preserved parts of an area by itself. The success of the protection and management of the protected areas depends on numerous stakeholders whose actions are connected to nature (Rientjes, 2000.). Be- 
cause of the increased public interest in questions concerning nature conservation, a need for participative public involvement in managing nature conservation areas grows stronger. The participation of key stakeholders in the planning of natural areas is of vital importance, since their interests concerning these areas as well as their ideas of how and why natural values are worth preserving can differ considerably. Legal support of the protection measures taken on protected areas results in certain limits regarding these areas, all the sectors must pay regard to while planning and intervening. This fact leads to a question, whether it would not be more reasonable for these areas to be founded with an agreement, or even better, with participation of all their stakeholders. The most common excuses for avoiding stakeholder participation are prolonged time periods and higher costs. The most dangerous is the belief of experts, that it is best, if the area is defined and managed exclusively by the professionals with their scientific approach and knowledge. However, even the opinions of the professionals may differ and their decisions are not always directly based on their profession, hence the public may participate the planning of the protected areas in early stages of the process already (Rowe and Frewer, 2000.). Given the fact that nature conservation faces interdisciplinary questions, a transparent process of choice-making is necessary. The counterargument to the participation of stakeholders at certain decisions concerning nature conservation is the NIMBY (Not In My Back Yard) syndrome; the insufficient representation of persons involved and their lack of interest in the subject matter (Ogorelec, 1995.).

The public participation in the process has many advantages. The most important of them is the increased trust in the purpose of a protected area, which leads to a higher possibility for the protective measures to be successful and to an efficient implementation of the management plans. With public participation, it is easier to legitimize a protected area or its management plan and to reduce the conflicts between various interest groups. Additionally, the knowledge of locals they can fully express only if given a chance of an actual participation is not to be ignored (Raymond et al., 2010.).

The success of participation is not always the same. There is no ideal way of integrating stakeholders in the process. We are always faced with question when, whom and how to involve them in the process. Despite the well-planned strategy, success is not always guaranteed. Each case is unique because of the specific social and natural context, therefore, the results of the process of participation vary.

By presenting examples of the planned involvement of stakeholders in the planning of protected areas and their outcomes, we contribute to a wide range of knowledge about different ways of participation of different stakeholders in different situations. Analyses of such cases contribute to improvement of the participation process. In this article we analyze two examples of public participation in the process of establishment of protected areas in Slovenia. 


\section{The Legal Participation Basis}

The participation in environmental issues is increasing with institutionalized legal rights of the stakeholders or interested public. In the last decades, the participation is limited to a few international documents forming an important basis for the development of the participation in environmental decisions. In the article Our Common Future, better known as Brundtland report (World Commission on Environment and Development, 1987.), saving the question of sustainable development, the public participation is emphasized using the following words: "Most important, effective participation in decision-making processes by local communities can help them articulate and effectively enforce their common interest and "The law" alone cannot enforce the common interest. It principally needs community knowledge and support, which entails greater public participation in the decisions that affect the environment". This work is the foundation for the convening of the Earth Summit and the adoption of the Rio Declaration and Agenda 21, which also include and encourage participation. The Principle 10 of the Rio Declaration (The United Nations Conference on Environment and Development, 1992.) is wholly dedicated to public participation, stating that the best way of managing the environmental issues is with the participation of interested stakeholders at the relevant level. In order to achieve this, it is necessary to provide the access to environmental information. Additionally, this principle refers to Aarhus Convention - The United Nations Economic Commission for Europe [UNECE] Convention on Access to Information, Public Participation in Decision-making and Access to Justice in Environmental Matters (UNECE, 1998), which definitely resulted in the greatest step towards active environmental democracy and the possibility of public cooperation in environmental issues. It consists of three pillars: the right to access the environmental information, the right of public participation in environmental decision - law- and policy-making and the right of the legal protection of the first two rights. Last but not least is important to mention The European Landscape Convention, known as Florence Convention (Council of Europe, ETS No. 176, 2000.) which establish procedures for the participation of the general public, local and regional authorities, and other parties with an interest in the definition and implementation of the landscape policies. The legal protection of rights concerning involvement in decision-making processes institutionalizes the participation (Reed, 2008.), thus forming the foundation for improvement of planning conditions in the protected areas.

In the legislation of the European states, the participation in environmental decisions is more or less regulated. Slovenia is ratified Aarhus Convention in 2004. and the European Landscape Convention in 2003. In the Slovene spatial legislation, the Principle of Freedom of Information ensures an open access to environmental data, the right to participate in the processes concerned with changing of regulations, policies, strategies, programmes, plans and projects referring to the protection of environment and the right to participate in the processes of issuing concrete legal acts concerning the activities affecting the environment (Environment Protection Act, Ur.l. RS 39/06). The public has the right of information on the preparation processes of spatial acts and the right of participation in these processes. The access to spatial acts and the public information on the issues concerning spatial planning have to be 
ensured. The spatial act has to be publicly accessible and discussed for at least 30 days. The authorities have to consider public comments and suggestions and take a position on them (Spatial Planning Act, Ur.1. RS 33/07). Unfortunately, participation has not yet become common practice in the early stages of the planning process and is not encouraged in legal definitions in legislation.

\section{Whom, How and How Much to Involve in the Planning Process?}

Stakeholder participation can be defined as involvement of individuals and groups in the process of decision-making or planning, enabling them to influence decisions. Since the participation in itself does not lead to results, it is necessary to carefully plan it beforehand. The key question in participatory planning is the selection and the manner of including stakeholders (Kapoor, 2001., O'Rourke, 2005.). The stakeholders in planning of protected areas are, generally speaking, all the people with a common interest in a certain problem in whichever period of time, because it concerns and affects them or because they exert influence upon it directly or indirectly. The stakeholders can be individuals or groups active in all the levels form local to global (Freeman, 1984., Clarkson, 1995., Gass, Biggs and Kelly, 1997., Grimble and Wellard, 1997., Chevalier, 2001., Buanes et al., 2004.).

Before deciding on what methods to use to regulate stakeholder participation, we must therefore make a research on who are the key stakeholders in the protected area, who will be affected by the measures determined in the management plan and who will carry out these measures. The public participants should comprise a broadly representative sample of the population of the affected public (Rowe and Frewer, 2000.:13). In order to get the best results from experts as well as from the public, the participation levels and methods must be adapted according to the purpose we want to achieve with the structure of stakeholders. In many areas, numerous methods under the common name stakeholder analysis are widely used. Nowadays, they are one of the most common tools in natural resource management (Chevalier, 2001., Billgren and Holmén, 2008.). They help us identify the stakeholders and the connections between them, categorize them, understand their views on the problems, find out what conflicts exist between individuals or groups, find the key stakeholders and estimate their influence. With help of stakeholder analysis, it is easier for the planners to decide who to include in the planning process and at what level and how to do it, which has the most significant influence on the process of cooperating with stakeholders and possibly on its result as well (Grimble and Wellard, 1997., Billgren and Holmén, 2008., Reed et al., 2009.). The methods are based on identification, categorization and analysis of the relations between stakeholders (Reed et al., 2009.).

The transparency and independency of the decision of who and for what reasons has been included in the decision-making process in planning is of vital importance (European Communities [EC], 2003.). When the key stakeholders have been chosen, we decide what methods we will use to cooperate with them and when to use them in order to come closer to consensus-based decisions and plans, which are the prerequisite for a sustainable management of protected areas. 
Before deciding on the method of stakeholder participation or before planning of participation in a protected area, it is recommended to answer a question asked by Creighton (2005.: 11): "What kind of participation is required for the decision to have the legitimacy it needs so that once an agency reaches a decision, it is able to implement that decision?" The answer will help us choose the participation level and, consequently, the methods to be used (Höppner, Frick and Buchecker, 2008.). Participatory methodologies are often characterized as being reflexive, flexible and iterative, in contrast with the rigid linear designs of most of the conventional science (Cornwall and Jewkes, 1995.). According to the relevant literature, there are several methods for participation of stakeholders in the planning process. Their classification can be difficult, since the methods intertwine and complete each other. The most logical division is the grouping of participatory methods according to the level of public inclusion in the decision-making process.

Naturally, there are several levels of how strong the public influence is in the decision-making process. When public involvement has reached the level of true participation, it is already very high on the ladder. There are many authors of participation ladders concerned mostly with participation in planning and urbanism, however, these ladders are so generic they can apply to participation levels in any field. The number of levels the ladders consist of differs, but they are similarly structured as regard the content. One of the first such ladders is "A Ladder of Citizen Participation" (Arnstein, 1969.). The ladder extends from the state of no participation to absolute participation. Arnstein names its levels from "non-participation" to "citizen-power", while Pretty (Pretty et al., 1995.) in "A Typology of Participation" defines the levels from "Passive Participation" to "Self-Mobilization". Cornwall (2003.) mentions four modes of participation: functional, instrumental, consultative and transformative, each with a higher level of participation. At the first levels, the participation is limited only to informing people of coming events or sometimes even of the events that have already taken place. The communication is one-sided; it is usually held by experts or persons in any way affected by the change. Subsequent ladder levels can already be defined as partially participatory, since they introduce two-sided communication. People are listened to or involved in the process in some other way (e.g. via polls and questionnaires). These levels involve the consultation of experts with people. The experts define problems and solutions, which can be slightly modified according to peoples' responses. At these levels, the experts do listen to people, but they are still the only ones who decide whether or not the suggestions and opinions will be taken into account and to what extend. The following levels aspire to absolute participation or sometimes even to absolute decision-making power of the people involved. On the Pretty's ladder, this participation stage is preceded by an also relevant $5^{\text {th }}$ level, nowadays strongly present in Slovenia, regarding the founding of protected areas. At this level, people try to influence decisions by gathering in civil groups usually formed when the plan is in the final stages of adoption or even after the plan has already been adopted. The highest levels assign the decision-making power to the people who actively involve themselves in the process and see to its implementation. At this highest stage, the experts only "serve" public interests. In the similar manner, the participation is divided into co-knowing, co-thinking and co-operating (EC, 2003.). 
Unfortunately, the public is still only informed or educated about a certain matter in the protected area. The use of these tools cannot be classified as an actual participation, their selection, however, is vast. In most cases, these methods apply to a large number of people according to the principle to inform a large number of people with one single message' (Rientjes, 2000.). Public participation in planning is passive or limited to minimum. The participants are usually the people already motivated to change their opinion or behaviour, because of which the experts have already been questioning the efficiency of these methods. The most commonly used methods in this category are: news releases, brochures, posters, open houses, different events, websites, open telephones, public education meetings, public hearings etc. A higher cooperation level can be expected from another group of methods of more interpersonal nature the planners use in order to acquire information, knowledge, advice and suggestions on alternative solutions. This group of methods is useful in strategic planning, during which various opinions on problems and possible solutions are gathered. Here, the communication and cooperation are already two-sided. In order to gather information and opinions with the planner having a complete authority to decide what to take into consideration and to what extend, questionnaires and opinion surveys, interviews and focus groups are used. A special form of participation is referendum, giving the participants only the authority to decide between alternative options without having an influence on them. Higher participation levels introduce the third group of methods, which can still be of consultative nature, passing, however, a certain amount of decision-making power on the participants (Chess and Purcell, 1999., Buchy and Hoverman, 2000., Rowe and Frewer, 2000.). These methods include interactive workshops, roundtables, advisory and planning committees, citizen's jury and panels, consensus conferences, negotiation, mediation, etc. Some of the methods forming the second and third group can be used as soon as at the very beginning of the planning process, since the participants can help us determine how and where they see the advantages and disadvantages of the plan and gather ideas, solution possibilities and alternatives for further planning.

The participation in planning in natural areas is usually not limited to only one method, but includes a rather vast selection of them. The selection varies according to at what level in the planning process we apply them and to who are the stakeholders we cooperate with. The best results can be gained by including the public in the planning process as soon as possible, ideally before the official drawing of the border and protecting of the natural area. In this manner, the people will be more interested in the cooperation in drawing of the management plan.

The selection of the participation manner does not necessary affect the result. The use of various participation manners can have similar effects while the same participation manners can lead to different results. The success of the participation can be estimated in two ways: according to the success of the participation process alone or to the success of its result (Chess and Purcell, 1999.). According to Reed (2008.), the quality of decisions made through stakeholder participation is strongly dependant on the nature of the process leading to them. 
Before arranging the involvement of public or stakeholders in planning of protected areas, the reasons for participation have to be considered. The ideal level of public involvement in the process is, of course, relative. It depends on the results we expect or on the problem we want to solve.

\section{The Participation in Planning in Protected Areas in Slovenia}

In Slovenia, Stakeholder Involvement in the Planning Processes of the protected areas is nowadays given more attention. The largest improvement can be observed in the interdisciplinary and inter-institutional cooperation at the strategic level, while the participation of non-institutionalized stakeholders (local inhabitants, users etc.) remains less present at least in the first planning stages. A considerable problem arises from the lack of strategic plan of stakeholder cooperation from earlier planning phases onward and of the continued cooperation with stakeholders even after the one-time task has been accomplished. For sustainable management to be successful, the participation of these stakeholders is important especially in those categories of the protected natural area, in which one of the reasons for the qualities contributing to the protection of the area were obtained is a good management of it by the people living in balance with their natural environment (especially the International Union for Conservation of Nature [IUCN] categories II - National Park and $\mathrm{V}$ - Protected Landscape). In the field of stakeholder cooperation in protected areas in Slovenia, a good practice is indicated by the projects carried out in various protected areas (e.g. Krajinski park Goričko, Kozjanski park). The participation first reaches its peak as late as when it comes to drawing of management plans. Individual examples of good participation practice include various workshops, mediations, group discussions and roundtables in landscape- and regional parks involving land owners. The participation possibility and, consequently, its legal protection are defined in recent legal acts regulating different protected areas. The Triglav National Park [TNP] is ensuring and implementing public participation via forum of interested public of TNP. The forum consists of periodical public meetings regulating the management of the park. In the following part of the article, we specified stakeholder participation in two areas where in the recent years, a lot of attention and means has been dedicated to stakeholder and public cooperation.

\subsection{The Regional Park Snežnik}

Despite of planned stakeholder communication and participation, the outcome is not always predictable. It is namely influenced by various factors and interactions between them, making it impossible to wholly anticipate it. The founding of the Regional Park Snežnik was terminated before it was accomplished. The planned borders of the park comprised approximately $1000 \mathrm{~km}^{2}$ (Figure 1), and would, if founded, be the largest protected area in Slovenia. The Slovene regional parks belong in the category $\mathrm{V}$ with minor areas being a part of categories I - Strict Nature Reserve and II according to IUCN categorization. 
The idea of a park was first introduced in 1967. Based on the fact that Cerknica and Planina flooding plains were endangered due to planned hydroelectric power stations, the government proposed an act on Notranjsko karst park as soon as in 1986. However, the act was neither discussed nor adopted. The park was intended to protect the karst system of Ljubljanica River and should comprise $150 \mathrm{~km}^{2}$. Later on, the Slovene National Institute for Protection of Natural and Cultural Heritage suggested quite a few expansions of the park and a change of its name. In the following years, the idea of the future park developed on a local level and was supported by regional non-governmental organization the Notranjsko Ecology Centre [NEC]. The knowledge and awareness of the inhabitants concerning natural and cultural values of the area improved due to numerous activities, workshops and the inclusion in the project LIFE (1995.-1997.). The local initiators financed their activities by engaging in projects. The involvement in the project "Designing a model of local support of the Regional Park Snežnik" was supported by the Dutch governmental programme MATRA (Programme Social Transformation - project programme aims on the support of the transition into a democratic consitutional state in countries in Middle and East Europe and selected neighbour countries south of the European Union) during the years 1996. and 1999., which played an important role during the foundation of the park. Since the year 2000. the formal establishment process of the park is being led by the Institut of the RS for Nature Conservation at the Ministry of Environment and Spatial Planning [MOP].

Figure 1

Proposed Regional park Snežnik and established Notranjska Regional park
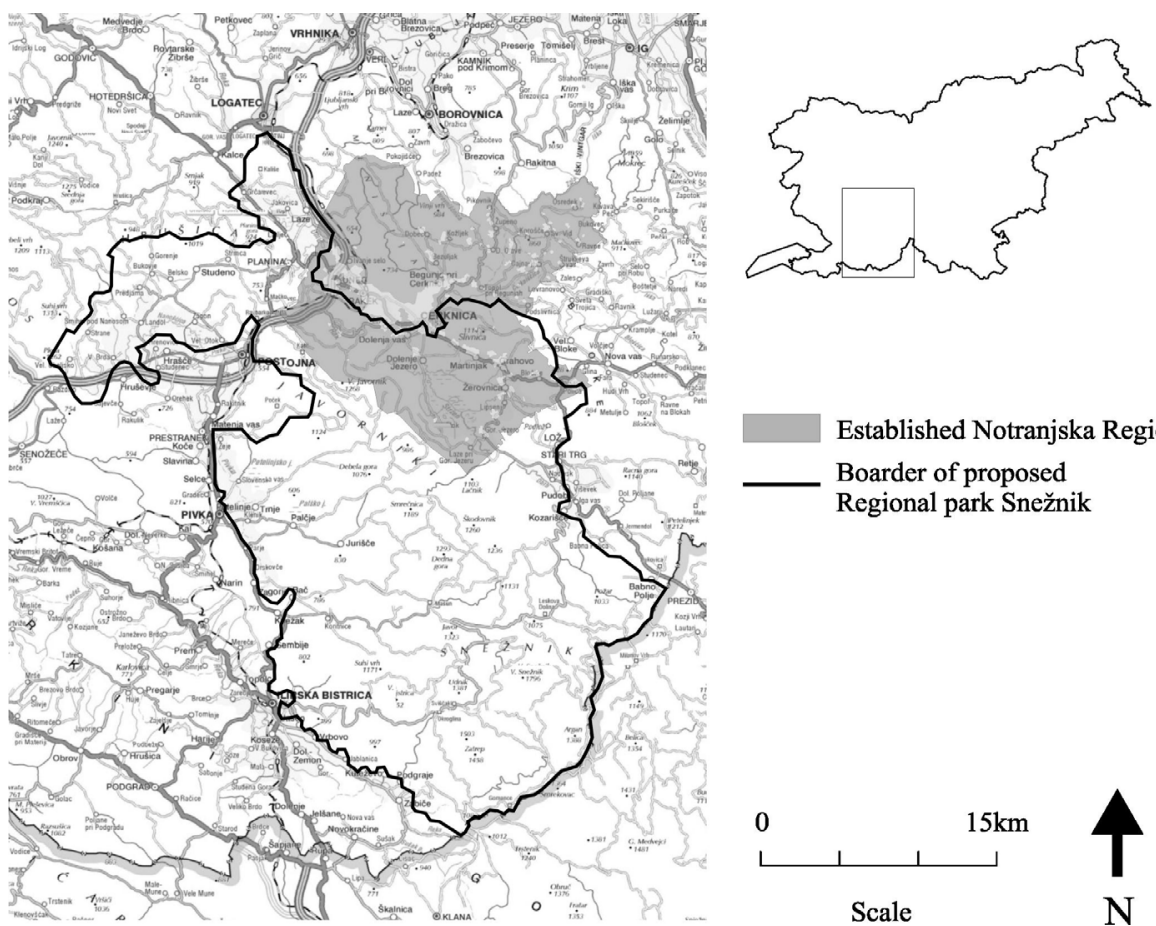

Established Notranjska Regional park

Boarder of proposed

Regional park Snežnik 


\subsubsection{Designing a Model of Local Support of the Regional Park Snežnik - MATRA}

The project executor was NEC in cooperation with Royal Dutch Society for Nature Conservation [KNNV]. It consisted of two parts: the preparation of the management and development plan for the park and the preparation of educational material concerning nature and its protection in favour of the park. The project encouraged the public consultation and cooperation in all the project phases. The approach to the planning of the park used in the project was concerned not only with nature conservation, but also with area's development. Its great advantage was that $80 \%$ of the experts involved in the process of preparing professional basis for the management plan were locals. In addition, the council of the project was founded, consisting of all the mayors of the communities involved as well as of the representatives of a few ministries and of qualified experts. In this way, the representatives of the communities were informed about the advancements in planning of the park from the very beginning onward and were thus able to express their comments and views at the same time. In 1999., the park was presented at the sessions of community councils of the communities within the park. The communities saw the park not only as a contribution to nature conservation, but also as a development opportunity. However, they pointed out that the locals should be informed about it as soon as possible (Ogorelec and Mastnak, 1999.).

Each phase of work done by the experts was discussed at workshops to which individuals, the representatives of local communities, management, non-governmental organizations, societies, institutes and ministries were invited. Additionally, the managers of existing Slovene parks and of Croation National Park Risnjak were invited to cooperation. The participants of workshops commented on the inventarisation work of experts in various ways, supplemented to it with their own suggestions and helped determining aims and measures resulting from the cooperation between working groups of experts and interest holders. A positive indicator of interest and content of the participants was their number getting higher with each of the following workshops. The participants cooperated actively (Ogorelec, 2010.). The wider public, especially the inhabitants of the park, were informed about their activities through mass media. Numerous media activities concerning the project have been carried out through radio, press, television and internet.

The planning methods in the MATRA project were based on the bottom-up principle including numerous key stakeholders and their interactive cooperation. Various interests were represented by a vast selection of people involved, trying to reach a consensus between them. The cooperation with KNNV in the MATRA project resulted in the material entitled as Starting points of a management plan (Ogorelec and Mastnak, 1999.). 


\subsubsection{The Formal Establishment Process - MOP}

After the MATRA project was finished, MOP the official founding procedure of the Regional Park Snežnik in the year 2000. by preparing a draft regulation. The professional basis of the draft was prepared by the Environmental Agency of the Republic of Slovenia based on the materials from the MATRA project resulting from the cooperation with various stakeholders. Even before the interdisciplinary consensus was reached, the communities gave suggestions and comments on the draft regulation. MOP considered them and included some of them in a new version of the draft regulation, which was discussed by community councils. Community councils did not oppose the foundation of the park; however, they observed a growing scepticism among the community members, mistrusting in the country leading the planning increasingly centralistic. They were worried about the development component of the park being too small, thus hindering the development of the communities. In their opinion, the communities should have more influence on the founding process and the community members should decide in a referendum whether they want the park to be founded or no (Ogorelec, 2010.).

During the foundation of the park, the inhabitants were not actively included in the communicative process. However, they were regularly informed about it from the beginning onward through various communication channels: news, press conferences, local and national newspaper articles, internet pages and through the bulletin Park Snežnik being published between August 2000. and March 2003. (21 numbers total). It was dispatched to all the households in the park and to all the significant stakeholders in its area (bigger companies, governmental and non-governmental organizations, libraries, journalists, researchers...). To the bulletin's disadvantage, the locals saw it as a free national advertisement. The bulletin directly informed the public about the park, thus reducing the number of "false rumours"; however, it was a rather passive way of passing information. Therefore, the bulletin kept changing the whole time long: the number of articles written by locals grew and it was supplemented by the articles promoting local tourism. Additionally, the bulletin included readers' letters, answers to the questions concerning the park, most frequently asked by locals, descriptions of natural phenomena of the park and the examples of a good practice in it. Interested public had a possibility to ask questions and express comments and concerns regarding the park, being given a telephone number and internet address. These are relatively fast and easily accessible ways of gathering required information; however, they exclude certain groups of people. The inhabitants used them but rarely (Ogorelec, 2002.).

\subsubsection{What Goes Wrong?}

In 2002., the inhabitants of a few villages in the park sent their collected signatures to the community mayors, expressing a wish to not be included in the park. The opposition grew even stronger due to the local industry (its employees being mostly the local inhabitants), disagreeing with the inclusion of certain areas in the park. 
The opponents did not use the offered communication channels, preferring to communicate with mayors, with whom regular coordination meetings were held in the process of writing the draft regulation. According to the estimations of the mayors, the country did not allocate enough resources for the park, which made them sceptical and decreased their support of the park (Ogorelec, 2010.).

Even in the process of founding the park, the inhabitants were not given any direct possibility of an active cooperation. Already in the MATRA project, where the cooperation was interactive, the workshops where not open to general public. The opposition of various groups of people was therefore more decisive in the official founding process.

During the project and the official founding process, no public opinion polling was carried out. Thus, "quiet" wishes and certain groups of people who did not express their opinion through the offered communication channels were overlooked. In the year 2002., the founding process was terminated even before inter-ministerial coordination of draft regulation was reached. The reason for that was the opposition of some of the inhabitants, industries and communities of the future park, unfavourable local pre-election atmosphere and the allocation of most of the MOP staff resources to priority Natura 2000 areas (Ogorelec, 2010.). The planning of the park was based on a different principle than the MATRA project. It was planned mostly in a top-down manner and reactively to the stakeholder initiatives, while the communication process of MATRA was proactive.

Because of the decreasing public support given to the foundation of the Regional Park Snežnik, the community Cerknica founded in 2002. the Notranjska Regional Park with the surface of $222 \mathrm{~km}^{2}$ (Figure 1) within its area. Additionally, it left open the possibility for the neighbouring communities to join the park and founded a public institute to manage it.

\subsection{The Shaping of Natura 2000 Areas in Slovenia}

\subsubsection{Advantages of the Communication Strategy}

Slovenia committed to submit a list if potential proposed Sites of Community Importance [pSCI] and a list of legally defined Special Protected Areas [SPA] to the European Commission until its in the European Community on 1st May 2004. Slovenia was given only 2 years for the whole project of defining the areas and communication, so a vast communicative project was carried out. The ministry strongly supported the communication planning, following the example of the communication model of pilot projects "Nature Management in Partnership" (project IUCNCEC, 2002.-2003.) emphasizing strategic communication planning, problem- and key stakeholder analysis and the determination of the concrete aims and communication strategy. In Slovenia, the share of Natura 2000 areas comprises 35.5\% of the national territory (Slovenian Environment Agency, 2010.) (Figure 2), which is the most of all 
the European Member States. Forests cover 71\% of the Natura 2000 (Government of the Republic of Slovenia, 2007.), so we would like to present an example of good practice by the Organization of the Forest Service in Slovenia below. The list of pSCI areas was made based on professional criteria. The challenge the communication group had to face was the planning of communication with numerous stakeholders in a very limited period of time. The main aims of communication strategy were informing the key stakeholders and increasing the concept of acceptance at the national as well as at the regional level (Hlad, 2004.), providing information, awareness raising and better understanding of Natura 2000: where and why the sites are being designated and the concerned implications (constraints and opportunities), indicating that the main aim of the first project phase was to inform and to raise the awareness of what Natura 2000 is with the intention to reduce possible negative public reactions. One of the expected results of the communication strategy is "a snapshot of stakeholders' attitude towards nature protection contents, issues and reasons for or against Natura 2000 in individual sites within the local communities". According to Hlad (2004.), the participation of higher levels was planned for the second phase of the project Natura 2000 - while forming management plans after accepting the areas. The project contributed to quite well-defined starting points for future Natura 2000 management and communications, giving a greater emphasize to active stakeholder participation in preparing and carrying out the management measures situation changes (Hlad and Kline, 2004.).

Figure 2

Natura 2000 in Slovenia

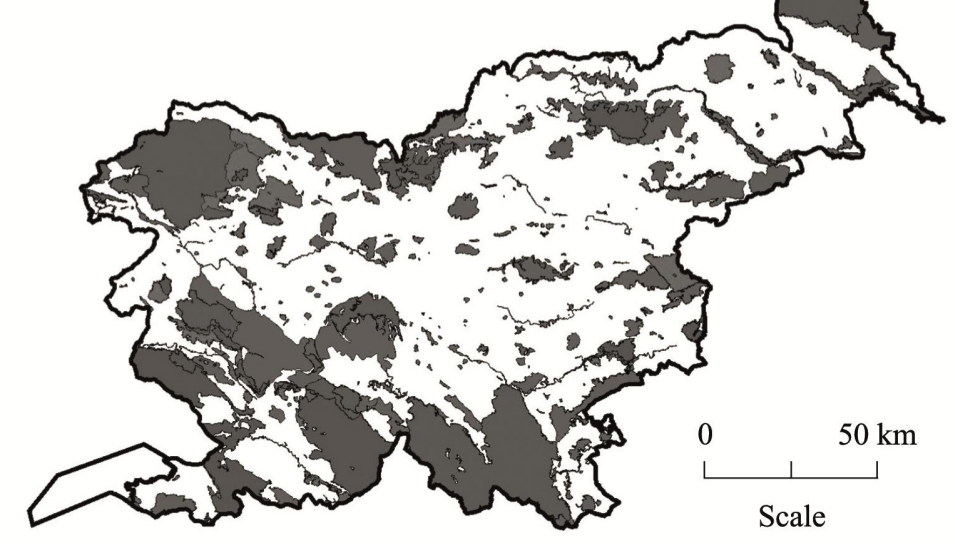

The producers estimate the communication plan and its execution to be very successful despite difficult circumstances, which became even an advantage. The determination of Natura 2000 areas was one of the conditions for acceptance in the European Community, which contributed to the political support of the project. The short period of time given urged a project-based approach resulting in a higher level of effectiveness and performance, while the lack of staff encouraged the cooperation with external contractors - communication experts (Ogorelec, 2010.). Positive communication results were a consequence of close interinstitutional cooperation and internal communication between the Ministry of the Environment and Spatial 
Planning and the Ministry of Agriculture, Forestry and Food (between ministries and governmental organizations), which decided for a strategic project partnership. A great advantage of the communicative project strategy was a much earlier approach to public then in the case of other nature conservation areas founded by then. Minor communication groups consisting of staff members of Institute of the Republic Slovenia for Nature Conservation [IRSNC], Slovenian Forest Service [SFS] and Chamber of Agriculture and Forestry of Slovenia [CAFS] prepared communication plans for the selected areas with help of the council provided by external communication experts and professional moderators of collective processes. The communication groups approached key stakeholders even at the local level before the final shaping of the areas and all the final expert-contributed data.

Communication was adapted for each individual area by smaller communication groups. Its basis was direct, personal communication with stakeholders; indirect communication had only a supportive role. Thus, the possibility of misunderstanding and misinterpretation is diminished at the very beginning. In the personal communication, the greatest attention was given to the stakeholders having the strongest influence on the changing of behaviour patterns and, consequently, on broader social changes. The communicative groups communicated mostly with communities, but also with key stakeholders: foresters, agronomic consultants, veterinaries, water industry representatives, regional development agencies, land owners, inhabitants, tourist-, mountaineering-, and with fishing- and hunting societies (Hlad and Kline, 2004.). Based on the reports of the communication groups, stakeholder responses were gathered in order to use them for further cooperation with them, solving of possible conflicts, increasing local interests for the identification and formation of partnerships. Aside the direct communication, a net of communicators intended for on-field communication and help was formed alongside with the complete graphic design for Natura 2000 including leaflets and other media releases.

\subsubsection{Weaknesses of this Approach}

Because of the short amount of time the project Natura 2000 was given and because of the pressure Slovenia was facing due to its acceptance in the European Community, the communication groups could focus only on one part of the areas and communicate only with selected, in their opinion the most important stakeholders in these areas. The shortage of time in comparison with the vastness of the project caused the mobilization of the majority of nature conservation staff. Only a small share of staff and finances was assigned to stakeholder and public communication and cooperation. On one hand, personal approach and early communication with selected stakeholders contributed to a better understanding of the network function and to the reduction of opposition, while on the other hand, the lack of early communication in some areas caused mistrust and bigger problems with implementation of Natura 2000 (Hlad and Kline, 2004.). Despite the fact that public participation in Natura 2000 is not specified in the national legal order, there was a 6-day period before the final admission of the areas intended for communities to express their opinion about it. Consequently, some of the communities expressed complaint. 
The areas were not formed publicly. The mistrust grew stronger due to later nontransparent changes of the areas. The initial top-down forming of areas, based solely on the professional criteria, causes disagreements, especially in case of spatial planners and communities. The professional determination of the areas according to the principle of "the best available data" causes mistrust; according to the reproaches, the habitat types are not mapped for all the areas, the data are insufficient and the local knowledge has not been regarded enough.

\subsubsection{Good Practice with Stakeholders at the Forest Service in Slovenia}

In Slovenia, where there is a high degree of forest cover, forestry is one of the activities that manages natural ecosystems and is with its long tradition, one of the key factors of management of the protected areas. Forest management plans are also management plans for forest part of Natura 2000. Most regulations from society to maintain the environment in countryside landscapes are nowadays defined in central administration, either at European or national level. They are based on the identification of absolute values, best methods and categories, making control possible but without the flexibility to adapt to different local contexts. It may also happen that in their essence, the top-down perspectives are not really understood, or accepted, by those who have to implement them locally. Developed as scientific solutions, they often lead to standardisation, simplification resulting in a weakening of the local cultural identity (Pinto-Correia, Gustavsson and Pirnat, 2006.).

The organization of the SFS can be regarded as a good example how two different hierarchical levels, from the national down to the landowner level, are mixed and interconnected within the same institution. The Forest Act prescribes operational plans for 10-year management periods, integrating both natural and social aspects all forests. Because natural attributes of different forest types in forested landscapes are combined with the interests of forest owners and general public, the strategic long-term oriented goal for forest and nature protection management is met with local and far shorter-term goals of forest owners. We may regard such management plan as a meeting point of top-down and bottom up approach. On a strategic level, natural givens are evaluated through engineering methods in a scientific manner while social attributes are incorporated into forest management plans in local level. In this way local foresters are faced with forest owners, their wishes and expectations and practical goals, their feelings for local needs identity and history. In this way a specific participatory approach is established as local foresters, knowing their forest owners and often their uneasiness concerning the future can adopt their management plans according to local society.

In this way a new type of communication is established. According with new recommendations based on integration of contextual knowledge into management of landscape level it is expected that with more communicative approaches by advisors and administrators, stakeholder involvement should become easier and thus reinforced (Pinto-Correia, Gustavsson and Pirnat, 2006.). 


\subsubsection{Discussion and Suggestions}

Despite quality communication planning within Natura 2000 in Slovenia, problems considering the implementation of the network at the local level arise (World Wildlife Fund [WWF], 2003., WWF, 2004., WWF, 2006., IUCN, 2005.). Situation in Slovenia is not an exception. Also other associated EU member states have similar problems with implementation of Natura 2000 (eg. WWF, 2003., WWF 2004., IUCN, 2005., WWF, 2006., Suškevičs and Külvik, 2011.). The circumstances causing a slow implementation of Natura 2000 in Slovenia could be summarized in 3 main intertwining groups of problem-causing factors:

- Natura 2000 not being accepted by communities and spatial planners,

- $\quad$ the lack of information, understanding and knowledge of the Natura 2000 contents of key stakeholders and general public,

- $\quad$ negative experiences with a few illogical examples.

The discontent is the strongest on the communities encompassing a large share of the Natura 2000 areas. In almost 7\% of the communities (from 210 included), more than 90\% of the area is included in Natura 2000 (Skoberne, 2007.), which influences the community spatial planning, increases the costs due to evaluation of influences on the environment and prolongs the appointed time limits.

Most of the problems and misunderstandings arise from insufficient and incomplete knowledge of the Natura 2000. Even though compared to the EU average, the Slovene public is more highly aware of the Natura 2000, some of the key stakeholders remain insufficiently informed about the consequences and opportunities of the Natura 2000 network. In the year 2010., as many as 55\% of the Slovenes included in the research Attitudes of Europeans towards the issue of biodiversity - Analytical Report (Flash Eurobarometer, 2010.) lead by Gallup Organization already heard for Natura 2000. 26\% of them knew even what Natura 2000 means, which is $18 \%$ more than the European average. However, many people still believe that on the areas of Natura 2000, all the activities are forbidden (Ogorelec and Pristop d.o.o, 2007.). The lack of knowledge increases the fear of limitations and causes stereotypes. For a wider spatial insight and right information on Natura 2000 areas, a free internet spatial data base Nature Conservation Atlas in Slovenia or Europe-wide EU European protected areas - Natura 2000 interactive map are recommended.

To a small extend, one of the reasons for a negative public image of Natura 2000 areas are negative experiences of individuals or organizations with management measures. Many land users expressed mistrust in the professional judgement and unnecessary measures or restrictions of certain interventions in Natura, especially if such areas were created based on insufficient science information (Hlad and Kline, 2004.). People are afraid that Natura will have a restrictive influence on their private interests and well-being. Additionally, illogical situations appear, with restrictions in the Natura 2000 areas, which were in the past established antropogenically and want to be renewed. One of the problems is also a sudden end of Natura 2000 areas due to the national border with Austria despite of relatively unchanged natural conditions. Such situations deepen the mistrust in the professionals as well as in the network. 
The lack of time for communication in all the Natura 2000 areas and all the difficulties connected with the implementation led to logical continuation of communication after the areas had officially been formed. Between the years 2006. and 2007., a project called "The communication support of Natura 2000 in Slovenia" was carried out and later rewarded as the best Slovene communicative project in the year 2008 The project offered a reliable support to the management programme. The project included various activities contributing to the improvement of media recognition and general knowledge of Natura 2000. An important part of the project was the estimation of communication efficiency and monitoring as well as the evaluation of communicative activities through the analysis of media reports, measuring the success of the workshops for communicators, prize games, the analysis of comments given by the visitors of internet pages and the analysis of public opinion before the beginning and after the implementation of the project (Ogorelec and Pristop d.o.o., 2007.). Further communication strategy for the period between 2007. and 2012. focuses mostly on permanent continuative stakeholder communication as well as on reaching a better understanding and inclination to Natura 2000 and on the activities of some of the target groups in support of Natura.

The objective of Natura 2000 sites cannot be to conserve values in landscapes by preservation of objects or patterns but to understand the ever-going landscape dynamics not just in a purely scientific way but combined with a contextual way, i.e. how multifunctionality is affected and supported by different landscape users. Through such knowledge both parties land owners and outsiders may become able to develop visions for the future landscape functioning.

In order to achieve a better understanding of the network and active cooperation of stakeholders in the process of implementing the Natura 2000 measures, it is highly necessary for the stakeholders to be aware that one of the reasons the parts of nature included in Natura were preserved is a long-lasting good managing by the people living in these areas a close-to-nature life. With the implementation of Natura, this condition only stays preserved and protected against future devaluations. But unfortunately, many people still believe Natura to be just another set of restrictions of their management and nature intervention. Public information alone reduces the fear of the unknown and, consequently, the stereotypes of nature conservation areas serving only as a "reservation protection" of natural values. But most of all, it is important for the people to get to know the possibilities and values of Natura 2000 and not understanding them just as a restraint. The involvement and mobilization of local stakeholders in active preparation and implementation of measures are of key importance, since only in this way, the stakeholders can come to understand their role in preserving the contents of Nature and to feel responsible for their actions (Höppner, Frick and Buchecker, 2008.).

In addition, the overview of the measures taken in various Natura areas and information on different sources for financing measures and development project in the Natura 2000 areas should be enabled. A large part of Natura 2000 is privately owned and used also in economic purposes. Therefore, the involvement of owners in the future management is necessary (European Commission, 2004.). The examples of 
good praxis in Slovenia and other countries encourage landowners to proactive measure implementation, forming of partnerships and applying for financial help regarding measure implementation. The management plans unite all the information on protection in one place where everyone has the access to it. In this way, a discussion and cooperation with stakeholders can be formed.

Only by constant communication with stakeholders and bottom-up participation in planning and carrying out management and sector plans, the stakeholders will be motivated to understand the value and the possibilities of the Natura 2000 network and will be ready to contribute to its preservation. For an easier Natura management- and continued cooperation planning, not only a monitoring enabling a continued following of the condition for the preserved species would be welcome, but also a continued following of social support and understanding if the wider concept of the Natura 2000 network, indirectly indicated by the nature condition as well. The communication and cooperation must be adapted to each area of the network separately. Considering the vastness of the network and the number of different stakeholders, it is difficult to unify the cooperation in the process of preparing and implementing the management measures, except from general directives and frames.

\section{Conclusion}

With two high-profile cases on protected area designation in Slovenia, we have represented the importance of planning and implementing the communication and participation with stakeholders. The summary of advantages, disadvantages of the cases and some proposed guidelines for future work are shown in the Table 1 and Table 2. Experiences gained in this way may be an inspiration for future implementation of protected areas i.e. NATURA 2000 which will need an integration of multifunctionality. Solutions should become flexible and create the conditions for the identification and application of specific solutions to specific places. Thus, the general knowledge and requirements of society could be integrated with the more contextual knowledge, aimed at discussing and formulating what could be considered realistic and concrete in each landscape (Pinto-Correia, Gustavsson and Pirnat, 2006.). In this way a new authenticy may be developed. Authenticity represent deep human need for recognition of owners roles in landscape management, which today are too often missing or marginalized in landscape policy contexts. They are part of the landscape experience and are linked to important feelings such as identity, responsibility, engagement and belonging, in relation to local territories (Pinto-Correia, Gustavsson and Pirnat, 2006.).

Despite numerous advantages of the participatory planning, it is necessary to be aware that this approach is not an absolute solution and a basis for conflict-free and long-lasting functioning of multifunctional natural environments. From numerous projects including public, we expect too much and, what is more, too fast. For a successful participation, the planning process must be open to possible changes of final decisions as of planning at the strategic level. According to Cornwall and Jewkes (1995.: 1673) the participatory research is certainly not a simple alternative. One has 
to be aware of numerous variables influencing the planning result: the representativeness and time of stakeholder involvement, the use of various methods and last, but not least the uniqueness and individuality of each situation. The generalization of rules in such planning usually cannot be applied; after all, the planning is set in a natural environment and includes working with people, none of which is entirely predictable, since both include a considerable number of unknown features. The success depends on the implementation of the whole participation process. The individual cases increasingly show that the key to a permanent and a successful functioning of the protected area is trust of the stakeholders in the protection aims, manners of their achievement and in the consensus between them.

Table 1

Advantages and disadvantages of the designation process of Regional Park Snežnik with some proposed guidelines.

\begin{tabular}{|c|c|c|c|}
\hline & Advantages & Disadvantages & Guidelines \\
\hline 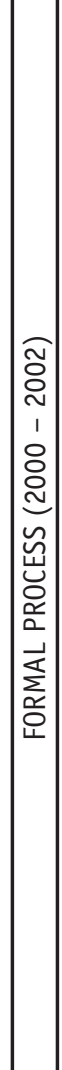 & 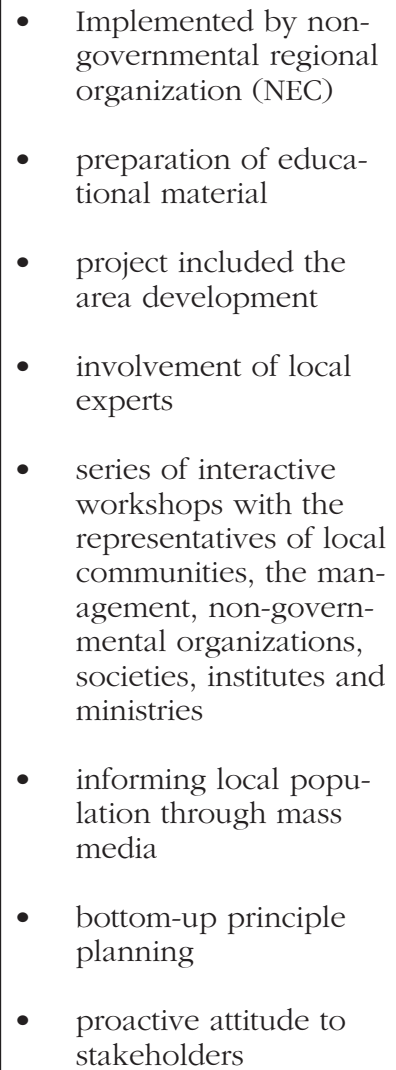 & $\begin{array}{l}\text { Excluding of non- } \\
\text { institutionalized stake- } \\
\text { holders (inhabitants, } \\
\text { users, etc) } \\
\text { No public opinion } \\
\text { research during the } \\
\text { project }\end{array}$ & $\begin{array}{l}\text { The idea of the park } \\
\text { and the most of early } \\
\text { stages of designation } \\
\text { should be held at the } \\
\text { local and regional } \\
\text { level with the key lo- } \\
\text { cal stakeholders } \\
\text { for improved commu- } \\
\text { nication and partici- } \\
\text { pation a stakeholder } \\
\text { analysis needs to be } \\
\text { done in order to find } \\
\text { the key stakehold- } \\
\text { ers and their position } \\
\text { toward the subject } \\
\text { strategic plan of stake- } \\
\text { holder cooperation } \\
\text { from early on and } \\
\text { continued coopera- } \\
\text { tion with stakeholders } \\
\text { after designation }\end{array}$ \\
\hline
\end{tabular}




\begin{tabular}{|c|c|c|c|}
\hline & Advantages & Disadvantages & Guidelines \\
\hline 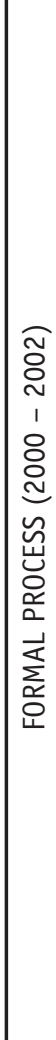 & $\begin{array}{l}\text { Directly informing } \\
\text { local population } \\
\text { through mass media } \\
\text { info telephone, e- } \\
\text { mail, website, bulletin } \\
\text { contributions from lo- } \\
\text { cal inhabitants in the } \\
\text { bulletin - two-way } \\
\text { communication } \\
\text { cooperation with } \\
\text { communities }\end{array}$ & $\begin{array}{l}\text { Top-down principle } \\
\text { planning } \\
\text { rare use of info tel- } \\
\text { ephone and e-mail by } \\
\text { inhabitatnts } \\
\text { - } \quad \text { perception of the bul- } \\
\text { letin as a free national } \\
\text { advertisement } \\
\text { no direct communi- } \\
\text { cation with some of } \\
\text { key local stakeholders } \\
\text { (landowners, indus- } \\
\text { try, etc) } \\
\text { distrust of the state } \\
\text { and the centralized } \\
\text { procedure, lack of } \\
\text { financial funding for } \\
\text { the park } \\
\text { reactive attitude to } \\
\text { stakeholders } \\
\text { no public opinion } \\
\text { research during the } \\
\text { formal process of } \\
\text { establishment }\end{array}$ & $\begin{array}{l}\text { - directly informing the } \\
\text { population before } \\
\text { formal process of } \\
\text { designation and draft } \\
\text { regulation } \\
\text { - non-institutionalized } \\
\text { stakeholders should } \\
\text { have a chance to be } \\
\text { actively involved }\end{array}$ \\
\hline
\end{tabular}

Table 2

Advantages and disadvantages of the designation process and operation of the Natura 2000 sites with some proposed guidelines.

\begin{tabular}{|c|c|c|c|}
\hline & Advantages & Disadvantages & Guidelines \\
\hline 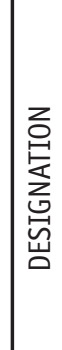 & $\begin{array}{l}\text { - Interdisciplinary and } \\
\text { inter-institutional } \\
\text { cooperation at the } \\
\text { strategic level; } \\
\text { - } \quad \begin{array}{l}\text { project-based ap- } \\
\text { proach; }\end{array} \\
\text { strong political sup- } \\
\text { port; }\end{array}$ & $\begin{array}{l}\text { Initial top-down form- } \\
\text { ing of areas; } \\
\text { communication } \\
\text { groups could focus } \\
\text { only on one part of } \\
\text { the areas and com- } \\
\text { municate only with } \\
\text { selected stakeholders; }\end{array}$ & $\begin{array}{l}\text { - Integration of multi- } \\
\text { functionality; } \\
\text { - } \\
\text { flexibility to adapt to } \\
\text { different local con- } \\
\text { texts; }\end{array}$ \\
\hline
\end{tabular}




\begin{tabular}{|c|c|c|c|}
\hline & Advantages & Disadvantages & Guidelines \\
\hline 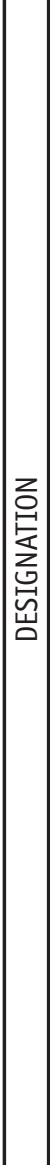 & $\begin{array}{l}\text { cooperation with exter- } \\
\text { nal contractors - commu- } \\
\text { nication experts; } \\
\text { vast and well planned } \\
\text { communication project; } \\
\text { earlier approach to pub- } \\
\text { lic than in the cases of } \\
\text { other previously founded } \\
\text { nature conservation } \\
\text { areas. The communica- } \\
\text { tion groups approached } \\
\text { key stakeholders even at } \\
\text { the local level before the } \\
\text { final shaping of the areas } \\
\text { and all the final expert- } \\
\text { contributed data; } \\
\text { communication was } \\
\text { adapted for each indi- } \\
\text { vidual area; } \\
\text { direct, personal commu- } \\
\text { nication with key stake- } \\
\text { holders; } \\
\text { stakeholder responses } \\
\text { were gathered in order } \\
\text { to use them in further } \\
\text { cooperation }\end{array}$ & $\begin{array}{l}\text { the main aim of the 1st } \\
\text { project phase was to } \\
\text { inform and to raise the } \\
\text { awareness and reduce } \\
\text { possible negative public } \\
\text { reactions. The partici- } \\
\text { pation of higher levels } \\
\text { was planned only for } \\
\text { the second phase of the } \\
\text { project- after forming } \\
\text { management plans and } \\
\text { accepting the areas; } \\
\text { public participation in } \\
\text { Natura } 2000 \text { is not speci- } \\
\text { fied in the national legal } \\
\text { order; } \\
\text { communities expressed } \\
\text { complaint to the only } \\
\text { 6-day period to express } \\
\text { their opinion; } \\
\text { the areas were not } \\
\text { formed publicly. The } \\
\text { mistrust grew stronger } \\
\text { due to later non-trans- } \\
\text { parent changes of the } \\
\text { areas; } \\
\text { the data for some } \\
\text { Natura } 2000 \text { areas are } \\
\text { insufficient and the local } \\
\text { knowledge has not been } \\
\text { regarded }\end{array}$ & 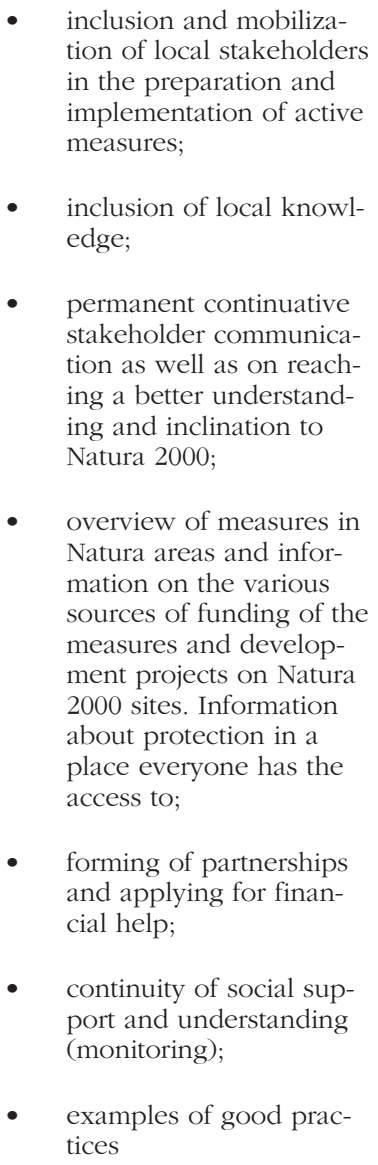 \\
\hline 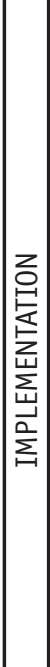 & $\begin{array}{l}\text { Continued communica- } \\
\text { tion after the designa- } \\
\text { tion; } \\
\text { Website: Nature Conser- } \\
\text { vation Atlas; } \\
\text { the Forest Service in } \\
\text { Slovenia is a good ex- } \\
\text { ample how two differ- } \\
\text { ent hierarchical levels, } \\
\text { from the national down } \\
\text { to the landowner level, } \\
\text { are mixed and intercon- } \\
\text { nected within the same } \\
\text { institution }\end{array}$ & $\begin{array}{l}\text { Natura } 2000 \text { not being } \\
\text { accepted by communi- } \\
\text { ties and spatial planners; } \\
\text { a lack of informa- } \\
\text { tion, understanding } \\
\text { and knowledge of the } \\
\text { Natura } 2000 \text { contents. } \\
\text { Knowledge of the key } \\
\text { stakeholders and general } \\
\text { public is still not suf- } \\
\text { ficient; } \\
\text { negative experiences } \\
\text { with few illogical exam- } \\
\text { ples; } \\
\text { distrust of the owners of } \\
\text { the Natura } 2000 \text { toward } \\
\text { non- cooperation in the } \\
\text { designation process }\end{array}$ & \\
\hline
\end{tabular}




\section{References}

1. Arnstein, S. R. (1969). A ladder of citizen participation. Journal of American Institut Planners, 35 (4): 216-224.

2. Billgren, C. and Holmén, H. (2008). Approaching reality: Comparing stakeholder analysis and cultural theory in the context of natural resource management. Land Use Policy, 25 (2008): 550-562.

3. Buanes, A.; Jentoft, S.; Karlsen, G. R.; Maurstad, A.; Søreng, S. (2004). In whose interest? An exploratory analysis of stakeholders in Norwegian coastal zone planning. Ocean \& Coastal Management, 47 (2004): 207-223.

4. Buchy, M. and Hoverman, S. (2000). Understanding public participation in forest planning: a review. Forest Policy and Economics, 1 (2000): 15-25.

5. Chess, C. and Purcell, K. (1999). Public Participation and the Environment: Do We Know What Works? Environmental Science \& Technology, 33 (16): 26852692.

6. Chevalier, J. (2001). Stakeholder analysis and natural resource management. Read on 20 2010. (http://http-server.carleton.ca/čjchevali/STAKEH2.html).

7. Clarkson, M.B.E. (1995). A stakeholder framework for analyzing and evaluating corporate social performance. Academy of Management Review, 20 (1): 92-117.

8. Cornwall, A. (2003). Whose Voices? Whose Choices? Reflections on Gender and Participatory Development. World Development, 31 (8): 1325-1342.

9. Cornwall, A. and Jewkes, R. (1995). What is participatory research? Social Science EMedicine, 41 (12): 1667-1676.

10. Creighton, J. L. (2005). The public participation handbook. Making Better Decisions Through Citizen Involvement. San Francisco: Wiley.

11. Environment Protection Act, Uradni list RS 39 from 2006.

12. European Communities (2003). Common Implementation Strategy for the Water Framework Directive (2000/60/EC). Guidance document no. 8. Public Participation in relation to the Water Framework Directive. Read on 14 April 2009. (http://circa.europa.eu/Public/irc/env/wfd/library?l=/framework directive/guidance documents/guidancesnos8spublicspar/ EN 1.0 \&a=d).

13. European Commission, Environment Directorate General (2004). LIFE-Nature: communicating with stakeholders and the general public - Best practice examples for Natura 2000. Luxembourg: Office for Official Publications of the European Communities.

14. European Landscape Convention, Council of Europe, ETS No. 176 from 2000

15. Flash Eurobarometer (2010). Attitudes of Europeans towards the issue of biodiversity. Analytical report. Wave 2. Hungary: The Gallup Organisation.

16. Freeman, R.E. (1984). Strategic Management: a Stakeholder Approach. Boston: Pitman.

17. Gass, G.; Biggs, S. and Kelly, A. (1997). Stakeholders, science and decision making for poverty-focused rural mechanization research and development. World Development, 25 (1): 115-126.

18. Government of the Republic of Slovenia (2007). Operational Programme Natura 2000 Management Programme 2007 - 2013. Ljubljana: Government RS.

19. Grimble, R. and Wellard, K. (1997). Stakeholder methodologies in natural resource management: a review of principles, contexts, experiences and opportunities. Agricultural systems, 55 (2): 173-193. 
20. Hlad, B. (2004). Natura 2000. Final Report on the Implementation of the Communication Strategy. Ljubljana: Ministry of Environment and Spatial Planning.

21. Hlad, B. and Kline, M. (2004). Natura 2000. Končno poročilo o izvajanju Komunikacijske strategije. Priloga 10: Priporočila za upravljanje in komuniciranje Natura 2000. Ljubljana: Ministry of the Environment and Spatial Planning.

22. Höppner, C.; Frick, J. and Buchecker, M. (2008). What Drives People's Willingness to Discuss Local Landscape Development? Landscape Research, 33 (5): 605-622.

23. International Union for Conservation of Nature (2005). Implementation of Natura 2000 in New EU Member States of Central Europe. Assessment Report. Warsaw: IUCN Programme Office for Central Europe.

24. Kapoor, I. (2001). Towards participatory environmental management? Journal of Environmental Management, 63 (3): 269-279.

25. O'Rourke, E. (2005). Landscape Planning and Community Participation: Local Lessons from Mullaghmore, the Burren National Park, Ireland. Landscape Research, 30 (4): 483-500.

26. Ogorelec, B. (1995). Komuniciranje z javnostjo. Priročnik za urbaniste. Ljubljana: Urban Planning Institute of the Republic of Slovenia.

27. Ogorelec, B. (2002). Ustanavljanje regijskega parka Snežnik - izkušnje s komuniciranjem, in: Aarbuška konvencija v Sloveniji. Strokovna priporočila za implementacijo Konvencije o dostopu do informacij, udeležbi javnosti pri odločanju in dostopu do pravnega varstva $v$ okoljskih zadevah. Ljubljana: Regionalni center za okolje za srednjo in vzhodno Evropo.

28. Ogorelec, B. (2010). Interview and Personal Communication. Ministry of Environment and Spatial Planning, Avgust 2010.

29. Ogorelec, B. and Mastnak, M. (1999). Izhodišča za načrt upravljanja. Vzpostavitev modela lokalne podpore $v$ Regijskem parku Snežnik - projekt MATRA. Ljubljana: Ministry of Environment and Spatial Planning.

30. Ogorelec, B. and Pristop d.o.o. (2007). Krepitev implementacije Nature 2000 $v$ Sloveniji - Komunikacijska podpora implementaciji Nature 2000. Končno poročilo. Ljubljana: Ministry of Environment and Spatial Planning.

31. Pinto-Correia, T.; Gustavsson, R. and Pirnat, J. (2006). Bridging the gap between centrally defined policies and local decisions - Towards more sensitive and creative rural landscape management. Landscape Ecology, 21 (3): 333-346.

32. Pretty N. J.; Guijt, I.; Thompson, J.; Scoones, I. (1995). Participatory learning and action. A Trainer's guide. London: IIED.

33. Raymond, M. C.; Fazey, I.; Reed, M. S.; Stringer, L. C.; Robinson, G. M.; Evely, A. C. (2010). Integrating local and scientific knowledge for environmental management. Journal of Environmental Management, 91 (8): 1766-1777.

34. Reed, M. S. (2008). Stakeholder participation for environmental management: A literature review. Biological Conservation, 141 (10): 2417-2431.

35. Reed, M. S.; Graves, A.; Dandy, N.; Posthumus, H.; Hubacek, K.; Morris, J.; Prell, C.; Quinn, C. H.; Stringe, L. C. (2009). Who's in and why? A typology of stakeholder analysis methods for natural resource management. Journal of Environmental Management, 90 (5): 1933-1949. 
36. Rientjes, S. (Ed.) (2000). Communicating nature conservation. A manual on using communication in support of nature conservation policy and action. Tilburg: European Centre for Nature Conservation.

37. Rowe, G. and Frewer, L. J. (2000). Public Participation Methods: A Framework for Evaluation. Science, Technology \& Human Values, 25 (1): 3-29.

38. Slovenian Environment Agency (2010). Register območij Natura 2000. Read on 20 May 2011. (http://kazalci.arso.gov.si/?data=indicator\&ind_id=333).

39. Skoberne, P. (2007). Delež območij Natura 2000 po občinah. Ljubljana: Ministry of Environment and Spatial Planning.

40. Spatial Planning Act, Uradni list RS 33 from 2007.

41. Suškevičs, M. and Külvik, M. (2011). The Role of Information, Knowledge, and Acceptance During Landowner Participation in the Natura 2000 Designations: The Cases of Otepää and Kõnnumaa, Estonia, in: The European Landscape Convention. Challenges of Participation. Dordrecht etc.: Springer.

42. The United Nations Conference on Environment and Development (1992). Rio Declaration on Environment and Development. Rio de Janeiro: The United Nations Conference on Environment and Development.

43. United Nations Economic Commission for Europe (1998). The UNECE Convention on Access to Information, Public Participation in Decision-making and Access to Justice in Environmental Matters - Aarhus Convention. Geneva: United Nations Economic Commission for Europe.

44. World Commission on Environment and Development (1987). Our Common Future. Read on 20 April 2010. (http://www.un-documents.net/wced-ocf.htm).

45. World Wildlife Fund (2003). Progress on Preparation for Natura 2000 in Future EU Member States. Synthesis and country reports for Bulgaria, Czech Republic, Estonia, Hungary, Latvia, Lithuania, Malta, Poland, Romania, Slovakia and Slovenia. Budapest: WWF.

46. World Wildlife Fund (2004). Natura 2000 in the New EU Member States. Status report and list of sites for selected habitats and species. Budapest: WWF.

47. World Wildlife Fund (2006). Natura 2000 in Europe. An NGO assessment. Implementation status of the Habitats Directive in the EU-25 Member States, Bulgaria, Romania, Croatia and Turkey. Budapest: WWF. 
Mojca Nastran

Biotehnički fakultet, Sveučilište u Ljubljani, Slovenija

e-mail:nastran.mojca@gmail.com

Janez Pirnat

Biotehnički fakultet, Sveučilište u Ljubljani, Slovenija

e-mail: janez.pirnat@bf.uni-lj.si

\title{
Učešće dionika u planiranju zaštićenih prirodnih područja: Slovenija
}

\begin{abstract}
Sažetak
Učešće dionika u planiranju zaštićenih prirodnih područja sve više dobiva na značaju. Participacija pridonosi povjerenju dionika u ciljeve zaštite i mjere upravljanja. Ograničeno vrijeme i financijska sredstva često svode utjecaj participacije dionika na razinu informacije i edukacije, što najčešće rezultira nedovoljnom primjenom izbora koji se odnose na zaštitu prirode. Članak opisuje glavne faze prostornog planiranja uz participaciju dionika, čime nam omogućava da odredimo identitet ključnih dionika, planirani stupanj participacije i metode koje treba koristiti za postizanje istih. Detaljna analiza participacije dionika i javnosti prilikom planiranja zaštićenih prostora u Sloveniji je izvedena na dva primjera: osnivanju Regionalnog parka Snežnik i oblikovanju područja Natura 2000. Participacija dionika i komunikacija prilikom osnivanja Regionalnog parka Snežnik bila je planska, međutim jedan od razloga zašto je osnivanje prekinuto prije nego je proces završen je opadanje javne potpore za park. Oblikovanje mreže Natura 2000 bilo je popraćeno opsežnim komunikacijskim pothvatom koji se bavio problemom kako pristupiti što većem broju dionika u kratkom zadanom vremenskom periodu. Članak pokazuje zašto primjena Nature 2000 u Sloveniji napreduje sporo i smjernice za njezino poboljšanje.
\end{abstract}

Ključne riječi: Arhuška konvencija, Zavod za šumarstvo, Matra, Natura 2000, metodologija participacije, regionalni park Snežnik - Slovenija, analiza dionika, participacija dionika. 